\title{
Resurrection of the Butterfly-winged Comber, Serranus papilionaceus Valenciennes, 1832 (Teleostei, Serranidae) and its phylogenetic position within genus Serranus
}

\author{
Adriana Vella ${ }^{1,2}$, Noel Vella ${ }^{1,2}$, Carolina Acosta-Díaz ${ }^{2}$ \\ I Conservation Biology Research Group, Department of Biology, University of Malta, Msida, MSD2080, \\ Malta 2 Biological Conservation Research Foundation, PO BOX 30, Hamrun, HMR 1000, Malta \\ Corresponding author: Adriana Vella (adriana.vella@um.edu.mt)
}

Academic editor: N. Bogutskaya | Received 12 November 2020 | Accepted 9 January 2021 | Published 12 February 2021

http://zoobank.org/F678A836-A14F-4851-8ECD-926D8C0061B7

Citation: Vella A, Vella N, Acosta-Díaz C (2021) Resurrection of the Butterfly-winged Comber, Serranus papilionaceus Valenciennes, 1832 (Teleostei, Serranidae) and its phylogenetic position within genus Serranus. ZooKeys 1017: 111126. https://doi.org/10.3897/zookeys.1017.60637

\begin{abstract}
The family Serranidae is represented by 92 genera and 579 valid species, with the genus Serranus Cuvier, 1816, containing 30 species. In this study, specimens of Butterfly-winged Comber, Serranus papilionaceus Valenciennes, 1832, were collected from the Canary Islands and compared morphologically and genetically to Painted Comber, Serranus scriba (Linnaeus, 1758), from the Mediterranean Sea. Morphological differences, especially in the colour banding pattern, were corroborated by genetic differences in mitochondrial (COI and ND2) and nuclear (Rhod and PTR) markers. The mitochondrial DNA markers revealed a high level of divergence and no shared haplotypes between the two species (interspecific divergence: COI 4.31\%; ND2 8.68\%), and a phylogenetic analysis showed that these two species are closely related sister species sharing common ancestry. This study is therefore offering to resurrect $S$. papilionaceus Valenciennes, 1832 as a valid species increasing the number of eastern Atlantic Serranus species to 11. This should direct new species-specific research, including its population conservation status assessment across its distribution.
\end{abstract}

\section{Keywords}

Butterfly-winged Comber, Canary Islands, Mediterranean Sea, Painted Comber, phylogeny, taxonomy

Copyright Adriana Vella et al. This is an open access article distributed under the terms of the Creative Commons Attribution License (CC BY 4.0), which permits unrestricted use, distribution, and reproduction in any medium, provided the original author and source are credited. 


\section{Introduction}

The family Serranidae, which is composed of sea basses and groupers, has three subfamilies Anthiadinae, Epinepheline, and Serraninae, which are represented by 579 valid species in 72 genera (Parenti and Randall 2020). The genus Serranus (Perciformes, Serranidae) has 30 small reef-associated species (Iwamoto and Wirtz 2018; Horton et al. 2020), with the most recent additions to the genus Serranus being S. aliceae Carvalho Filho \& Ferreira, 2013 from the Southwest Atlantic Ocean and S. pulcher Wirtz \& Iwamoto, 2016, S. drewesi Iwamoto, 2018, and S. inexpectatus Wirtz \& Iwamoto, 2018 from the Eastern Central Atlantic Ocean (Carvalho Filho and Ferreira 2013; Wirtz and Iwamoto 2016; Iwamoto and Wirtz 2018).

Most of the species belonging to this genus are recorded in the coastal regions of the Atlantic Ocean, with 14 species occurring in the Western Atlantic and 10 species within the Eastern Atlantic. In addition to these, another six species inhabit the Eastern Pacific Ocean while another two occur in the Indian Ocean (Iwamoto and Wirtz 2018). Both the Mediterranean Sea and the Canary Islands are known to host the same four Serranus species (Dooley et al. 1985; Bauchot 1987): the Blacktail Comber, S. atricauda Günther, 1874, which in the Mediterranean is restricted to the western basin; the Comber, S. cabrilla (Linnaeus, 1758); the Brown Comber, S. hepatus (Linnaeus, 1758); and the Painted Comber, S. scriba (Linnaeus, 1758). However, analysing photos of specimens commonly identified as $S$. scriba collected off the Canary Islands, we noticed distinct differences in colour pattern when compared to the specimens from the Mediterranean Sea, including Malta (Fig. 1), as was already observed by Iwamoto and Wirtz (2018). These notable differences led us to further investigate the species' identity using morphological and genetic analyses, while reviewing first descriptions and museum specimens to accurately identify the species in question.

\section{Materials and methods}

\section{Morphological analyses of sampled specimens}

Specimens were collected by local coastal fishermen during regular fishing activities in the Canary Islands using traps for fish $(n=12)$ and Malta during shoreline fishing $(n=15)$ between 2016 and 2017 (Figs 1, 2; Suppl. material 1: Table S1). The total length of each specimen was measured to the nearest millimeter using electronic callipers, and tissue samples were taken from each specimen. All the specimens collected from Malta and five specimens collected from the Canary Islands were morphologically examined following Heemstra and Randall (1993) and Zorica et al. (2010), where various body parts were measured to the nearest millimeter using electronic callipers and counts of the soft and hard rays in the dorsal, pectoral, pelvic, anal, and caudal fins were counted. 


\section{DNA and phylogenetic analyses}

Total genomic DNA was extracted using GF-1 DNA Extraction Kit (Vivantis Technologies, Malaysia) and used as a template for amplifying two mitochondrial DNA (mtDNA) genes [cytochrome oxidase c subunit 1 gene (COI); and NADH dehydrogenase subunit 2 gene (ND2)], and two nuclear DNA (nDNA) genes [rhodopsin gene (Rhod); and si:ch211-105n9.1-like protein, hypothetical protein LOC564097 (PTR)]. The amplification protocols were carried out following literature in Table 1. The PCR products were sequenced using their respective forward and reverse primers through 3730XL Genetic Analyzer (Applied Biosystems, USA).

Sequences were trimmed and the complimentary sequences of each individual were assembled using Geneious R10 (Kearse et al. 2012). Sequences were manually checked for consistencies. The final sequences were deposited in GenBank under accession numbers: MW439283-MW439309 (COI); MW447416-MW447496 (ND2; Rhodo; PTR) (Suppl. material 1: Table S2)

The mtDNA haplotype diversity and nucleotide diversity indices for both species were calculated via Arlequin v. 3 (Excoffier and Lischer 2010), while the intraspecific and interspecific $p$-distance was measured using DnaSP (Rozas et al. 2017). Parsimony haplotype networks were constructed via TCS (Clement et al. 2000) to analyse the association between the various haplotypes identified during this study. For nDNA genes, Geneious R10 (Kearse et al. 2012) was used to identify single nucleotide polymorphism between the two species.

To evaluate the phylogenetic relationship of the resurrected taxon to that of other Serranus species, COI sequences were imported from BOLD (Ratnasingham and Hebert 2007) and GenBank (NCBI 2020). Further details of these sequences are included in Suppl. material 1: Table S3. All the COI sequences were aligned using ClustalW (Thompson et al. 1994) and the sequences were trimmed to $578 \mathrm{bp}$ representing the smallest homologous sequence for this data set. The phylogenetic relationships between different Serranus species were evaluated through the construction of a phylogenetic tree using neighbour-joining analysis and the $p$-distance model (Collins et al. 2012; Srivathsan and Meier 2012; Collins and Cruickshank 2013). This analysis was conducted via MEGA v. 7 (Kumar et al. 2016) using 1000 bootstraps.

Table I. A list of the primers and amplification protocols used to amplify the genes used in this study.

\begin{tabular}{lccc}
\hline Gene & Primers & (5' to 3') & Reference \\
\hline COI & FishF1 & TCAACCAACCACAAAGACATTGGCAC & Ward et al. (2005) \\
& FishR1 & TAGACTTCTGGGTGGCCAAAGAATCA & \\
ND2 & ND2-MetF & AAGCTYTTGGGCCCATACC & Vella et al. (2017) \\
& ND2-TrpR & AGCTTTGAAGGCTTTTGGTYT & \\
Rhod & $193 \mathrm{~F}$ & CNTATGAATAYCCTCAGTACTACC & Chen et al. (2003) \\
& $1039 \mathrm{R}$ & TGCTTGTTCATGCAGATGTAGA & \\
PTR & Ptr_F458 & AGAATGGATWACCAACACYTACG & Chenhong et al. (2007) \\
& Ptr_R1248 & TAAGGCACAGGATTGAGATGCT & \\
\hline
\end{tabular}




\section{Historical material}

The following museum specimens' photographs and describing manuscript diagrams were analysed carefully, comparing the historic image evidence, when available, with the photographs taken from specimens sampled for this study.

Descriptions of $S$. scriba and its possible synonyms were reviewed given the close resemblance between $S$. scriba and the species being resurrected. Relevant scientific descriptions evaluated for this purpose included: Perca scriba described by Linnaeus (1758: 292) and Linnaeus (1764: 86); Perca marina described by Brünnich (1768: 63); Holocentrus fasciatus described by Bloch (1790: 86); Holocentrus marocannus described by Bloch and Schneider (1801: 320); Holocentrus argus described by Spinola (1807: 372); Serranus scriba described by Cuvier and Valenciennes (1828: 214); and Serranus papilionaceus described by Valenciennes (1832: 471).

\section{Holotypes}

Serranus scriba originally described as Perca scriba Linnaeus 1758; NRM 442; holotype status follows Fernholm and Wheller (1983) and Parenti and Randall (2020) • Holocentrus marocannus Bloch and Schneider 1801; Morocco; ZMB5531 (left skin); a junior synonym to Serranus scriba as noted in Cuvier and Valenciennes (1828), Gunther (1859) and Parenti and Randall (2020).

\section{Syntype}

Serranus papilionaceus Valenciennes 1832; Gorée, Senegal, Atlantic Ocean; two specimens MNHN-IC-0000-7279.

\section{Other material}

Serranus scriba; Algeria; two specimens MNHN-IC-0000-7129 • Serranus papilionaceus (labelled as Serranus scriba); Dakar, Senegal; collected in 1896; MNHNIC-1896-0389 - Serranus papilionaceus (labelled as Serranus scriba); Cap Blanc, Baie du Levrier, Mauritania; four specimens MNHN-IC-1999-1053.

\section{Results}

Based on the currently used literature and morphological keys (Bauchot 1987; Lloris and Rucabado 1998; Iwamoto and Wirtz 2018), all specimens collected and analysed during this study (Suppl. material 1: Table S1) fit the body shape description of S. scriba sensu lato; however, genetic data revealed divergence between the two forms. Based on the type specimens and descriptions evaluated in this study, we assigned the 
specimens collected from Malta to $S$. scriba in its traditional usage based on Cuvier and Valenciennes (1828). These specimens matched the museum specimens NRM 442 and MNHN-IC-0000-7129 (Suppl. material 1: Figs S1a, S2b). We assign the specimens collected from the Canary Islands to the resurrected taxon $S$. papilionaceus, as described by Valenciennes (1832) and matching the syntype specimens MNHN-IC-0000-7279 (Suppl. material 1: Fig. S2a) and museum specimens MNHN-IC-1896-0389 and MNHN-IC-1999-1053.

\section{Morphology}

\section{Meristic counts and measures}

Meristic counts (Table 2) indicated a general overlap between the counts of the two species investigated, with only the anal soft fin rays counts showing a difference (7 in S. scriba and 8 in S. papilionaceus). Though the meristic measures (Table 3) overlapped between the two species, the specimens investigated also showed a longer average dorsal fin length in $S$. papilionaceus than in S. scriba (46.3\% TL \pm 1.1 and $41.4 \%$ $\mathrm{TL} \pm 1.4$, respectively). Extended morphometric studies on S. papilionaceus covering a wider distribution and life-stages are required to corroborate the significance of these differences. Consequently, the most important identifying morphological characteristic feature between the two species would be their body colouration patterns described below.

Table 2. Meristic counts for Serranus scriba, its synonyms ${ }^{1}$ (Parenti and Randall 2020) and Serranus papilionaceus. Values in brackets represent the mean and SD for counts that have a range. ${ }^{2}$ Questionable locality (Fernholm and Wheller 1983).

\begin{tabular}{|c|c|c|c|c|c|c|c|}
\hline \multirow{2}{*}{$\begin{array}{l}\text { Species } \\
\text { name }\end{array}$} & \multirow{2}{*}{$\begin{array}{c}\text { References } \\
\text { (sample size) }\end{array}$} & \multicolumn{5}{|c|}{ Meristic counts } & \multirow[t]{2}{*}{ Locality } \\
\hline & & Dorsal & Pectoral & Ventral & Anal & Caudal & \\
\hline Perca scriba & Linnaeus, 1758 & $10 / 15$ & 13 & $1 / 5$ & $3 / 7$ & 15 & $\begin{array}{c}\text { America } \\
(\text { Linnaeus, 1764) }\end{array}$ \\
\hline Perca marina ${ }^{1}$ & Brünnich, 1768 & $10 / 16$ & 13 & $1 / 5$ & $3 / 8$ & 15 & Mediterranean \\
\hline $\begin{array}{l}\text { Holocentrus } \\
\text { fasciatus }^{1}\end{array}$ & Bloch, 1790 & $10 / 15$ & 13 & $1 / 5$ & $3 / 7$ & 16 & \\
\hline $\begin{array}{l}\text { Holocentrus } \\
\text { marocannus }\end{array}$ & $\begin{array}{c}\text { Bloch \& } \\
\text { Schneider, } 1801\end{array}$ & $10 / 16$ & 15 & $1 / 5$ & $3 / 7$ & 18 & Morocco \\
\hline $\begin{array}{l}\text { Serranus } \\
\text { scriba }\end{array}$ & $\begin{array}{c}\text { Cuvier \& } \\
\text { Valenciennes, } \\
1828\end{array}$ & $10 / 14$ & 13 & $1 / 5$ & $3 / 7$ & 17 & $\begin{array}{l}\text { Mediterranean: } \\
\text { France, Malta, } \\
\text { Italy and Egypt }\end{array}$ \\
\hline $\begin{array}{l}\text { Serranus } \\
\text { scriba }\end{array}$ & $\begin{array}{l}\text { Zorica et al. } 2010 \\
\qquad(\mathrm{n}=253)\end{array}$ & $\begin{array}{c}10 / 14-17 \\
(15.01 \pm 2.04)\end{array}$ & $\begin{array}{c}12-16 \\
(14.10 \pm 1.15)\end{array}$ & $\begin{array}{c}1 / 4-6 \\
(4.97 \pm 0.49)\end{array}$ & $\begin{array}{c}3 / 7-8 \\
(7.03 \pm 0.82)\end{array}$ & $\begin{array}{c}15-18 \\
(16.59 \pm 1.36)\end{array}$ & Trogir, Turkey \\
\hline $\begin{array}{l}\text { Serranus } \\
\text { scriba }\end{array}$ & $\begin{array}{l}\text { current work } \\
(\mathrm{n}=15)\end{array}$ & $10 / 15$ & $\begin{array}{c}13-14 \\
(13.27 \pm 0.46)\end{array}$ & $1 / 5$ & $3 / 7$ & $\begin{array}{c}15-17 \\
(16.67 \pm 0.62)\end{array}$ & Malta \\
\hline $\begin{array}{l}\text { Serranus } \\
\text { papilionaceus }\end{array}$ & $\begin{array}{c}\text { Valenciennes, } \\
1832\end{array}$ & $10 / 15$ & 16 & $1 / 5$ & $3 / 8$ & 17 & Gorée, Senegal \\
\hline $\begin{array}{l}\text { Serranus } \\
\text { papilionaceus }\end{array}$ & $\begin{array}{l}\text { current work } \\
(\mathrm{n}=5)\end{array}$ & $\begin{array}{c}10 / 15-16 \\
(15.40 \pm 0.55)\end{array}$ & $\begin{array}{c}14-15 \\
(14.60 \pm 0.55)\end{array}$ & $1 / 5$ & $3 / 8$ & 17 & Canary Islands \\
\hline
\end{tabular}


Table 3. External measures of Serranus papilionaceus and Serranus scriba expressed as a percentage of the total length.

\begin{tabular}{|c|c|c|c|c|c|c|c|c|c|}
\hline \multirow[t]{2}{*}{ Meristic measures } & \multicolumn{3}{|c|}{$\begin{array}{c}\text { Serranus papilionaceus } \\
\text { Canary Islands } \\
\text { current study }(n=5)\end{array}$} & \multicolumn{3}{|c|}{$\begin{array}{c}\text { Serranus scriba } \\
\text { Malta } \\
\text { current study }(n=15)\end{array}$} & \multicolumn{3}{|c|}{$\begin{array}{l}\text { Serranus scriba } \\
\text { Turkey } \\
\text { ica et al. } 2010(n=253)\end{array}$} \\
\hline & range & mean & SD & range & mean & SD & range & mean & SD \\
\hline Total length (mm) & $187-245$ & 216.6 & \pm 26.3 & $101-205$ & 131.8 & \pm 30.9 & $71-200$ & 110 & \pm 17.0 \\
\hline Standard length & $82.9-85.7$ & 84.5 & \pm 1.2 & $82.6-88.3$ & 85.3 & \pm 1.6 & $74.7-94.3$ & 84.3 & \pm 1.8 \\
\hline Head length & $28.9-33.9$ & 31.6 & \pm 2.0 & $31.8-35.6$ & 33.8 & \pm 1.1 & $16.8-40.0$ & 33.5 & \pm 1.6 \\
\hline Preocular head length & $8.9-10.0$ & 9.4 & \pm 0.4 & $8.0-10.2$ & 9.4 & \pm 0.6 & & & \\
\hline Eye diameter & $4.8-5.3$ & 5.1 & \pm 0.3 & $4.9-6.8$ & 6.2 & \pm 0.6 & & & \\
\hline Postocular head length & $14.3-17.6$ & 16.0 & \pm 1.5 & $15.8-18.8$ & 17.1 & \pm 0.8 & & & \\
\hline Predorsal distance & $28.6-32.9$ & 30.7 & \pm 1.6 & $31.2-35.9$ & 33.7 & \pm 1.3 & $28.9-43.5$ & 33.6 & \pm 1.9 \\
\hline Preanal distance & $52.4-56.7$ & 55.2 & \pm 1.6 & $53.0-59.2$ & 56.4 & \pm 1.9 & $48.3-64.8$ & 55.3 & \pm 1.9 \\
\hline Maximum body height & $24.2-25.8$ & 25.1 & \pm 0.6 & $22.9-28.7$ & 25.5 & \pm 1.5 & $16.8-47.1$ & 27.9 & \pm 2.6 \\
\hline Minimum body height & $10.7-11.7$ & 11.3 & \pm 0.4 & $9.0-10.2$ & 9.7 & \pm 0.3 & & & \\
\hline Length of dorsal fin & $45.3-47.6$ & 46.3 & \pm 1.1 & $39.8-44.1$ & 41.4 & \pm 1.4 & $31.0-47.4$ & 40.9 & \pm 1.4 \\
\hline Length of anal fin & $12.7-15.3$ & 14.0 & \pm 1.1 & $12.0-14.2$ & 12.9 & \pm 0.7 & $7.5-15.5$ & 12.2 & \pm 1.3 \\
\hline Length of pectoral fin & $18.4-23.0$ & 21.1 & \pm 1.8 & $21.1-23.8$ & 22.0 & \pm 0.8 & $17.4-27.8$ & 22.5 & \pm 1.4 \\
\hline Length of ventral fin & $17.6-21.6$ & 19.3 & \pm 1.6 & $15.6-17.4$ & 16.6 & \pm 0.5 & $10.3-21.0$ & 17.6 & \pm 1.4 \\
\hline Length of caudal fin & $16.3-18.6$ & 17.0 & \pm 0.9 & $11.7-17.4$ & 14.7 & \pm 1.6 & $5.7-18.4$ & 15.7 & \pm 1.4 \\
\hline
\end{tabular}

\section{Colour patterns}

The S. scriba (Fig. 1) specimens analysed in this study had nine dorso-ventral brown bands. The first band was observed to originate dorsally over the head and fade ventrally just behind the preopercular area. The second band, starting in front of the origin of the dorsal fin, was found to touch the back of the operculum and end at the origin of the pectoral fin. The third, shorter band originating at the first hard spine of the dorsal fin, fades away ventrally. The fourth and fifth band originating at the membrane between the fourth and the seventh hard spine of the dorsal fin and fade away ventrally. They are usually paired up and at times are nearly overlapping. The sixth and seventh band originating at the membrane between the eighth hard spine and the first soft spine of the dorsal fin, may at times be fused, and fade away ventrally into a bluish-violet blotch located over the abdomen area. The eighth and ninth bands are much wider than the former bands, appearing as two fused bands, especially when they fork out ventrally. These two wider bands originate from the soft spines of the dorsal fin and fade away ventrally as they approach the anal fin. A brown banding pattern on the tail peduncle is not always present. The pectoral fins, pelvic fins, anal fin, and tail peduncle together with the tail, are brownish-orange. A faint bluish colouration on the outer side of the pelvic fins and anal fin membrane is present. The pelvic fins, anal fin, dorsal fin, tail peduncle, and tail have red-orange spots, while at the tip of each hard spine of the dorsal fin there is a small, red-orange-coloured membrane. Yellowish thin vertical striations are visible on the abdominal area but quickly fade away ventrally. The head area is reddish-brown with vermiculation. The head area below the eye is light coloured, while the area above the eye has a darker red-brown colouration. A longitudinal brown stripe runs through the eye area. 


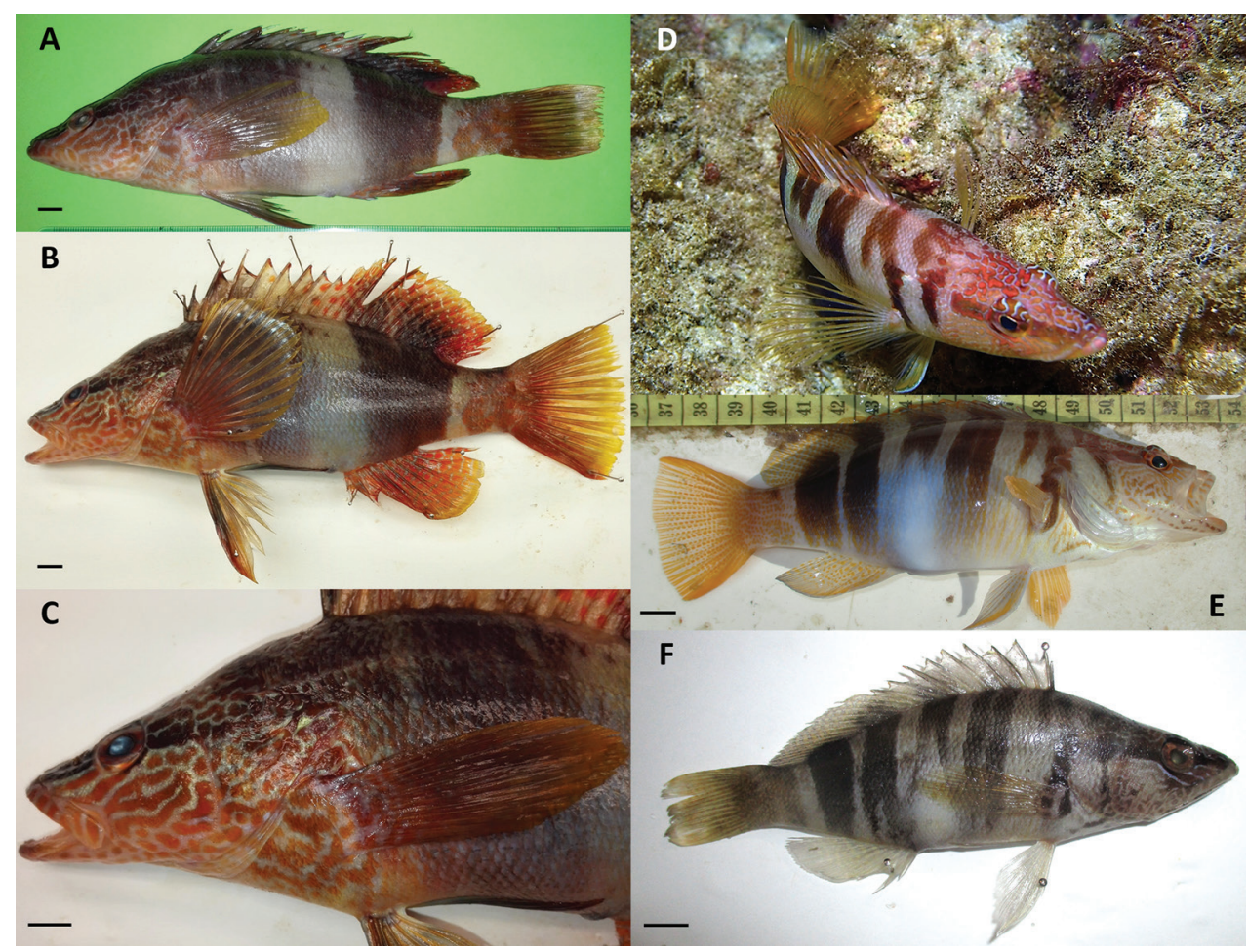

Figure I. A-C Serranus papilionaceus D-F Serranus scriba. Photos include details of specimens representing both species (underwater photography by Mr. P. Schembri, BICREF NGO). Scale bars: $1 \mathrm{~cm}$ $(\mathbf{A}-\mathbf{C}, \mathbf{E}, \mathbf{F})$.

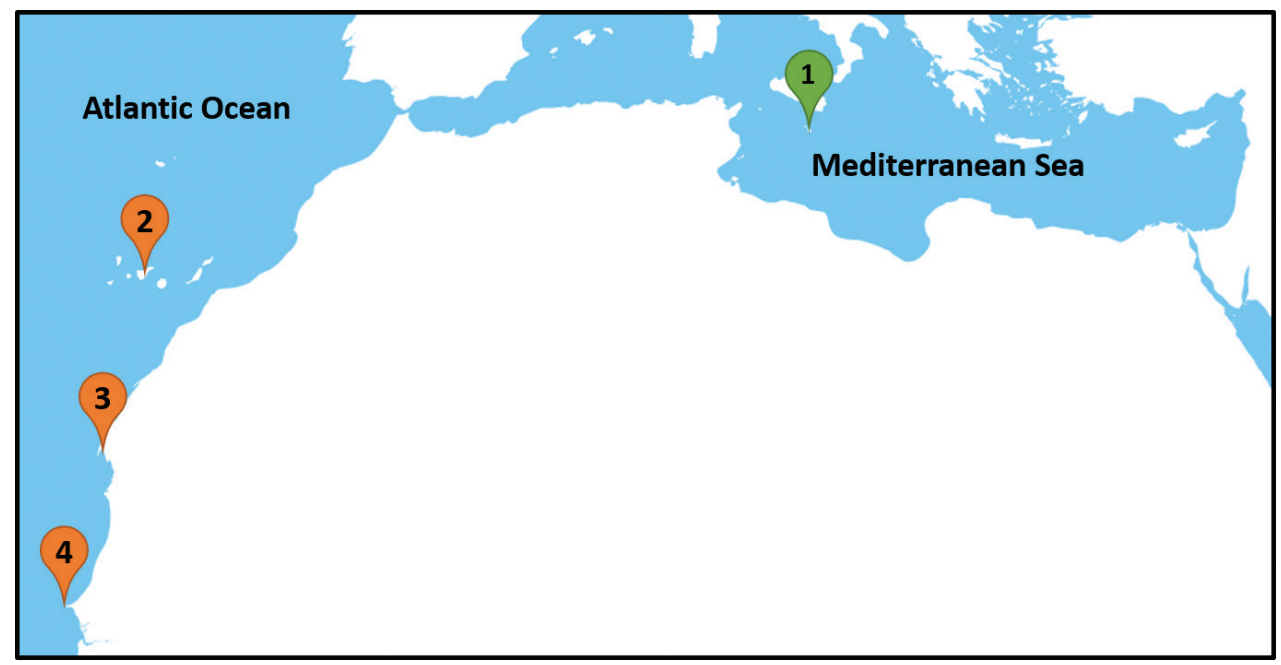

Figure 2. A map showing: the sampling locations for this study [1 - Malta, 2 - Canary Islands]; and the locations from where Serranus papilionaceus was recorded [2 - Canary Islands (Barker-Webb and Berthelot 1836; current study); 3 - Mauritania (MNHN-IC-1999-1053); 4 - Gorée, Senegal (Valenciennes, 1832; MNHN-IC-0000-7279; MNHN-IC-1896-0389)]. 
The banding pattern of the S. papilionaceus (Fig. 1) specimens examined in this study was composed of two wide dorso-ventral brown bands, at times each appearing as composed of multiple fused bands. The first anterior brown band, occurring between the head area and the membrane of the eighth hard spine of the dorsal fin, fades ventrally at the abdomen and was found to be longer than the bands noted in S. scriba. This brown band is followed by a lighter cream-coloured band originating between the last few hard spines and the first few soft spines of the dorsal fin. This light-coloured band ends with a blue-violet patch at the abdomen. The latter was not present in all specimens we examined, and when present, it was less conspicuous than that found on S. scriba. This light-coloured band is followed by another dorso-ventral, wide, brown band originating from the soft spines of the dorsal fin and which appears as being composed of multiple fused bands. A brown banding pattern is also visible on the tail peduncle. The pectoral fins, pelvic fins, and tail, are brownish-orange. The anal fin and the membrane of the soft-rays of the dorsal fin have red-orange spots that are more pronounced than those of $S$. scriba and are separated by bluish lines. The tip of each hard spine of the dorsal fin has a small, red-orange-coloured membrane. The head area of $S$. papilionaceus is brownish as opposed to the red-brown of $S$. scriba. In $S$. papilionaceus, the head area below the eye is lighter in colour than the dorsal area of the head. The vermiculation on the head is more pronounced in $S$. papilionaceus than in S. scriba, and as for the former species, the lighter patterns contrast more against the darker brown colouration. In $S$. papilionaceus, the brown longitudinal stripe that runs through the eye area is not as conspicuous as that of $S$. scriba.

Most of the vivid colourations noted on both S. scriba and S. papilionaceus are mostly visible on live specimens, and some of the details are lost once the individuals die; however, the main brown bands tend to remain visible for a longer time and remain persistent in some old museum preserved specimens (Suppl. material 1: Fig. S2).

\section{Genetic investigations}

\section{Genetic divergence}

The COI and ND2 data produced three and six haplotypes for the specimens collected from the Canary Islands $(n=12)$, while five and nine haplotypes were identified amongst the specimens collected from Malta $(n=15)$ for each respective gene (Table 4; Fig. 3). The intraspecific divergence for COI of the analysed specimens from Malta was

Table 4. The number of haplotypes noted ( $h a p$. .), the haplotype diversity ( $h$ ) and the nucleotide diversity $(\pi)$ at each gene for Serranus papilionaceus and Serranus scriba.

\begin{tabular}{lcccccc}
\hline \multicolumn{1}{c}{ mtDNA gene } & \multicolumn{3}{c}{ Serranus papilionaceus } & \multicolumn{2}{c}{ Serranus scriba } \\
\cline { 2 - 7 } & hap & $\boldsymbol{b}$ & $\boldsymbol{\pi}$ & hap & $\boldsymbol{b}$ & $\boldsymbol{\pi}$ \\
\hline COI (621 bp) & 3 & $0.621 \pm 0.087$ & $0.0011 \pm 0.0010$ & 5 & $0.476 \pm 0.155$ & $0.0009 \pm 0.0009$ \\
ND2 (846 bp) & 6 & $0.758 \pm 0.122$ & $0.0031 \pm 0.0020$ & 9 & $0.924 \pm 0.044$ & $0.0045 \pm 0.0027$ \\
concatenated (1467 bp) & 7 & $0.833 \pm 0.100$ & $0.0023 \pm 0.0014$ & 11 & $0.952 \pm 0.040$ & $0.0029 \pm 0.0017$ \\
\hline
\end{tabular}


$0.09 \%$, while on incorporating similar publicly available data for $S$. scriba from other areas of the Mediterranean ( $n=41$; Suppl. material 1: Table S3), the intraspecific divergence increased to $1.12 \%$, with all sequences clustering together on the same branch of the phylogenetic tree (Fig. 4). For the specimens collected from the Canary Islands, the intraspecific divergence on COI was $0.11 \%$. The genetic divergence between the two collections was found to be $4.31 \%$ (Table 5), that is four times larger than the intraspecific divergence, exceeding the species boundary delimitation of fish species (Ward et al. 2005). This led to the confirmation that specimens belonged to two different species. This large interspecific genetic difference was also noted on the ND2 gene where the intraspecific divergence was $0.45 \%$ and $0.31 \%$ for S. scriba and S. papilionaceus, respectively, while the interspecific divergence was $8.68 \%$ (Table 5), again surpassing the intraspecific divergence differences noted on the ND2 gene in other fish species by Naylor et al. (2012) and Vella et al. (2017). The haplotype networks of this mtDNA data show that the two species form two distinct clades, with no overlapping haplotypes (Fig. 3).

These results were further corroborated by both nuclear markers, where species specific SNPs were noted (Table 6). This data therefore confirms that genetically the specimens collected from the Canary Islands belong to a different species from those collected from Malta.

\section{Phylogeny}

All the species of Serranus found in the Mediterranean and the Canary Islands ( $S$. atricauda, S. cabrilla, S. hepatus, S. papilionaceus, and $S$. scriba) share the same ancestral branch of the phylogenetic tree (Fig. 4), with each species forming its own distinct clade. This phylogenetic tree placed S. scriba and S. papilionaceus as sister species to each other.

Table 5. Intraspecific and intraspecific average number of pairwise differences (percentage differences) for the mtDNA loci of Serranus papilionaceus and Serranus scriba.

\begin{tabular}{lccc}
\hline \multirow{2}{*}{ mtDNA gene } & \multicolumn{2}{c}{ Intraspecific divergence } & \multirow{2}{*}{ Interspecific divergence } \\
\cline { 2 - 3 } & Serranus papilionaceus & Serranus scriba & \\
\hline COI (621 bp) & $0.70(0.11 \%)$ & $0.53(0.09 \%)$ & $26.77(4.31 \%)$ \\
ND2 (846 bp) & $2.62(0.31 \%)$ & $3.79(0.45 \%)$ & $73.43(8.68 \%)$ \\
concatenated (1467 bp) & $3.32(0.23)$ & $4.33(0.30 \%)$ & $100.20(6.83 \%)$ \\
\hline
\end{tabular}

Table 6. SNPs noted for the nDNA loci of Serranus papilionaceus and Serranus scriba (a species-specific differences).

\begin{tabular}{|c|c|c|c|c|c|c|c|c|c|}
\hline nDNA gene & & & & Rhod & & & & & TR \\
\hline Position & 30 & 204 & $225^{a}$ & 232 & 273 & $628^{a}$ & $690^{a}$ & $160^{a}$ & $205^{a}$ \\
\hline Serranus & $\mathrm{C}(n=11)$ & $\mathrm{C}(n=15)$ & $\mathrm{G}(n=12)$ & $\mathrm{T}(n=9)$ & $\mathrm{C}(n=9)$ & $\mathrm{A}(n=15)$ & $\mathrm{C}(n=15)$ & $\mathrm{T}(n=12)$ & $\mathrm{G}(n=12)$ \\
\hline papilionaceus & $\mathrm{C} / \mathrm{T}(n=1)$ & & & $\mathrm{C} / \mathrm{T}(n=3)$ & $\mathrm{C} / \mathrm{T}(n=3)$ & & & & \\
\hline $\begin{array}{l}\text { Serranus } \\
\text { scriba }\end{array}$ & $\mathrm{C}(n=15)$ & $\begin{array}{c}\mathrm{C}(n=14) \\
\mathrm{C} / \mathrm{T}(n=1)\end{array}$ & $\mathrm{T}(n=15)$ & $\mathrm{C}(n=15)$ & $\mathrm{C}(n=15)$ & $\mathrm{G}(n=15)$ & $\mathrm{T}(n=15)$ & $\mathrm{C}(n=15)$ & $\mathrm{A}(n=15)$ \\
\hline
\end{tabular}



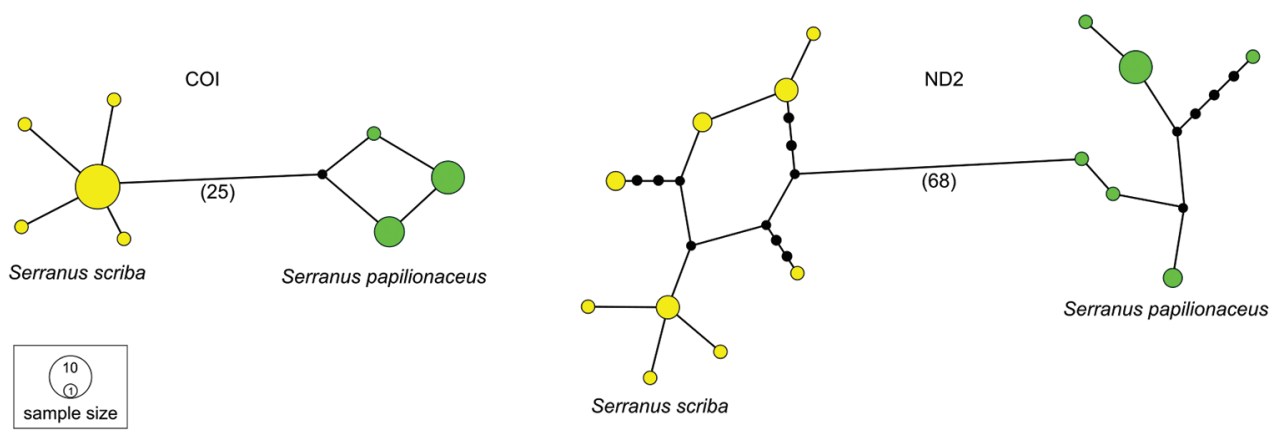

Figure 3. Two parsimony haplotype networks representing the genetic relationship between Serranus papilionaceus (Canary Islands) and Serranus scriba (Malta) for the COI and ND2 data (The haplotype frequencies are proportional with the area of the circle. The numbers in the brackets represent the number of interspecific substitutions, while the black circles represent inferred putative haplotypes within species that were not observed during this study).

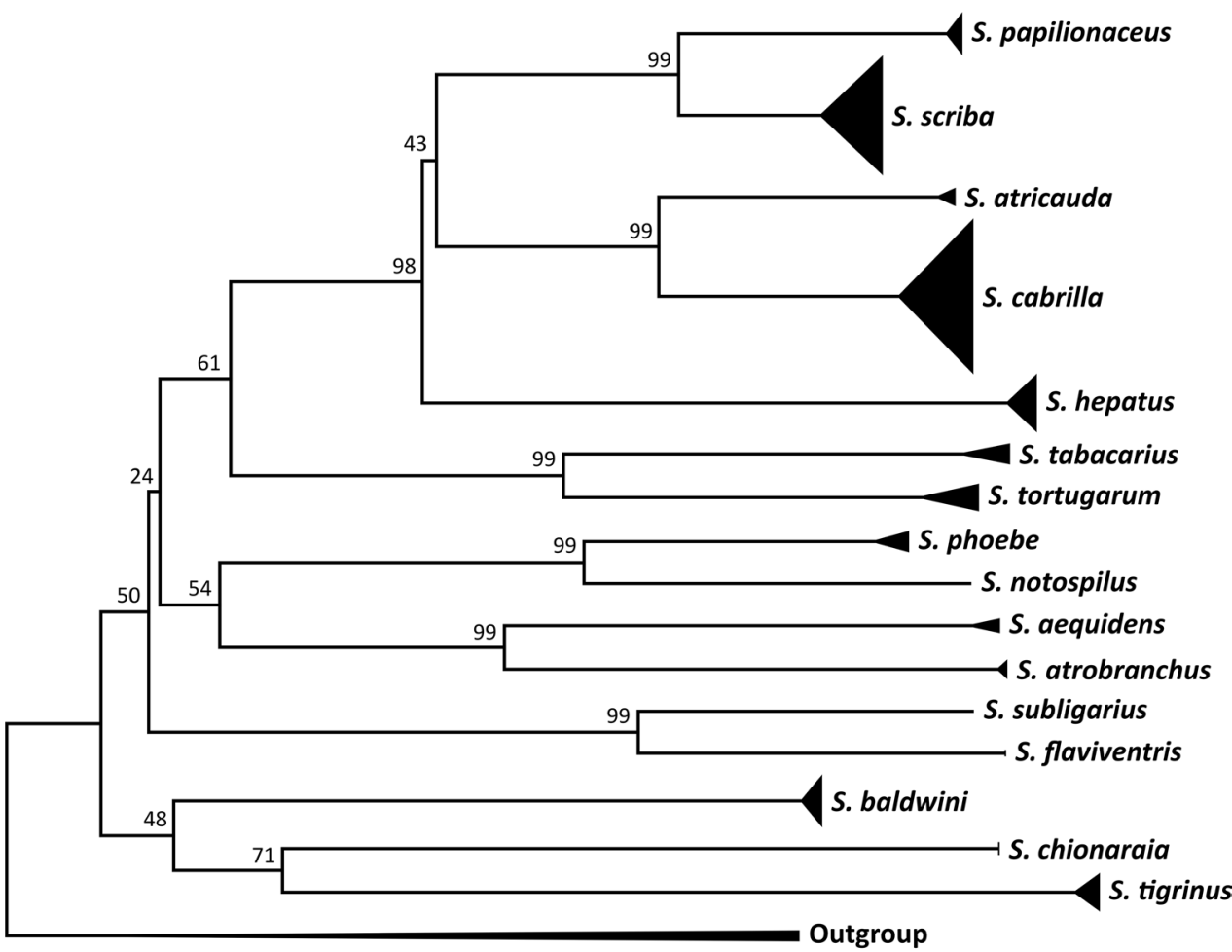

\subsection{1}

Figure 4. A neighbour-joining phylogenetic tree using p-distance. $186 \mathrm{COI}$ sequences (578 bp each) representing 16 different Serranus species were utilized (Suppl. material 1: Table S3). The numbers near nodes represent the bootstrap values. 


\section{Vernacular name}

We suggest Butterfly-winged Comber (Le Serran à Ailes de Papillon) as a common name of the species referring to its scientific name and the first description by Valenciennes (1832).

\section{Distribution}

Specimens of $S$. papilionaceus used in this work were collected from the coastal waters of the Canary Islands (Eastern Atlantic Ocean), the same archipelago where the species was recorded nearly two centuries ago by Barker-Webb and Berthelot (1836). The original description of Valenciennes (1832) also places this species at the island of Gorée off the coast of Senegal. Museum specimen MNHNIC-1896-0389 reconfirms this species at Senegal, while specimens collected from Mauritania (MNHN-IC-1999-1053) indicate that this species occurs also along the coast of this country (Fig. 2). The species might be more widely distributed along the western African coast and, therefore, more studies are required to better evaluate its distribution.

\section{Discussion}

Mitochondrial DNA data show that the genetic distance between the Mediterranean specimens of $S$. scriba and the ones collected from waters of the Canary Islands exceeded the intraspecific genetic distance (COI: 4.31\%; ND2: 8.68\%; Figs 3, 4) for both genes (Ward et al. 2005; Naylor et al. 2012; Vella et al. 2017), confirming that the specimens from these two different sampling sites belong to two different species. The morphological colour and banding pattern difference between these two species support the genetic distinction found.

Serranus scriba was first described by Linnaeus (1758: 292) as Perca scriba. This description is fairly brief and lacks the locality; however, specimen NRM 442 from the Swedish Museum of Natural History (Suppl. material 1: Fig. S1a) is believed to be the holotype for P. scriba (Fernholm and Wheller 1983; Parenti and Randall 2020). In Museum Adolphi Friderici volume 2, Linnaeus (1764: 86) updated the description of Perca scriba and included some more details on the colouration of the species, namely reticulations and undulations over the head and brownish transverse bands, relating it to the Mediterranean S. scriba. However, in this account Linnaeus (1764: 86) indicated America as its area of distribution (Fernholm and Wheller 1983). Cuvier and Valenciennes (1828) made a detailed description of S. scriba, providing an illustration of the species (plate 28; Suppl. material 1: Fig. S1b), as well as indicating its distribution as including the coast of Provence (France), Malta, Naples (Italy), and Alexandria (Egypt). This description matches the two museum specimens MNHN- 
IC-0000-7129 (Suppl. material 1: Fig. S2b) and the specimens collected from Malta for the current study (Fig. 1). We therefore keep the widely accepted S. scriba nomenclature here in reference to the Mediterranean species sampled and genetically investigated in this study.

After reviewing the possible junior synonyms for $S$. scriba (Fernholm and Wheller 1983; Smith-Vaniz 2015; Horton et al. 2020; Parenti and Randall 2020), it was noted that our specimens from the Canary Islands matched the description of $S$. papilionaceus (Valenciennes, in Cuvier and Valenciennes 1832: 471). Serranus papilionaceus was first collected from Gorée Island, Senegal, by M. Rang and described by Valenciennes (1832: 471), and it is represented by two extant syntypes in the Muséum National d'Histoire Naturelle (MNHN-IC-0000-7279; Suppl. material 1: Fig. S2a). Our findings corroborate the second account for this species as described by Barker-Webb and Berthelot (1836), who indicated that $S$. papilionaceus occurs in the Canary Islands. In the current study, we also reviewed the description of $H$. marocannus Bloch \& Schneider, 1801, as Peters (1865) suggested that this is synonymous to S. papilionaceus Valenciennes, 1832. However, given that the original description (Bloch and Schneider 1801: 320) and the quality of the type specimen (ZMB5531) lack the morphological details required to synonymise the two, we consider $H$. marocannus to be a junior synonym of S. scriba as noted by Cuvier and Valenciennes (1828), Gunther (1859), and Parenti and Randall (2020).

Historic records show that $S$. papilionaceus was accepted as a valid species name for a couple of decades (Barker-Webb and Berthelot 1836; Gunther 1859). However, by 1890 , studies on specimens from the Canary Islands were considered as the variant S. scriba var. papilionaceus (Dooley et al. 1985). As a result, the Butterfly-winged Comber had lost its status as a distinct species. The similarity between the two species was reported since the first description of S. papilionaceus, with Barker-Webb and Berthelot (1836) stating that the two species, considered here, were very similar and could be easily misidentified. Nonetheless, the banding pattern, especially of live specimens is the most distinctive morphological feature to differentiate between the two species. Additionally, the results of our genetic analyses confirm the genetic divergence between these two species.

The resurrection of $S$. papilionaceus adds another species to the genus Serranus, genetically sister to S. scriba (Fig. 4). This calls for new studies that look into the geographical distribution of both S. papilionaceus and S. scriba. Online searches for S. scri$b a$ indicate that the morphological details belonging to $S$. papilionaceus are present in photos that have originated from different coastal regions along the North-Eastern Atlantic Ocean, and we cannot exclude the possibility of potential range overlap of the two species in certain geographical areas.

Though Serranus species have been listed as Least Concern (Smith-Vaniz 2015; IUCN 2020), the conservation status of the now recognised distinct species, $S$. papilionaceus, needs to be evaluated. This is especially so when one considers that the Canary Islands had already listed their Serranus species as threatened some time ago (Bonnet and Rodriguez 1992; Tuset et al. 2005) and fishing pressures have not decreased. 


\section{Conclusion}

Genetic diversity investigation results and different body colour patterns observed have led us to resurrect $S$. papilionaceus Valenciennes 1832 as a species distinct from S. scriba (Linnaeus, 1758). Phylogenetic analysis confirmed that these two species are sister species within the genus Serranus and that their interspecific genetic divergence is four times larger than the usual intraspecific divergence in fish species. The resurrection of S. papilionaceus also emphasizes the required new research to understand the distinct distributions, threats, and conservation management of these species.

\section{Acknowledgements}

The research disclosed in this publication has been funded through the BioCon_Innovate Research Excellence Grant from the University of Malta awarded to AV. The authors would like to thank several fishers from Malta and the Canary Islands, who have supported this research and assisted in specimen collection. A special thanks goes to Jonathan Pfliger from the Muséum National d'Histoire Naturelle (France), Edda Aßel from Museum für Naturkunde - Leibniz Institute for Evolution and Biodiversity Research (Berlin, Germany), and Bo Delling and Anders Silfvergrip from the Swedish Museum of Natural History (Stockholm, Sweden) for providing the authors with the required information and photos of museum specimens. Additionally, thanks are also due to the scuba diver Patrick Schembri from the NGO BICREF for providing photography of live specimens from Malta. The three scientific reviewers of this manuscript are appreciated for their valuable feedback.

This study did not require ethical approval as it made use of dead specimens and tissue samples collected from specimens caught by local fishermen during regular fishing activities.

DNA sequences generated in this study have been deposited in GenBank. Details of the specimens and the associated accession numbers are included in the Suppl. material 1: Table S2.

\section{References}

Barker-Webb P, Berthelot S (1836) Histoire Naturelle des Îles Canaries. Tome deuxième. Ichthyologie des Iles Canaries ou Histoire Naturelle des Poissons. Béthune, Paris, 108 pp. https://doi.org/10.5962/bhl.title.60795

Bauchot ML (1987) Serranidae. In: Fischer W, Bauchot ML, Schneider M (Eds) Fiches FAO d'Identification des Espèces pour les Besoins de la Peche. Mediterranee et Mer Noire. Zone de peche 37 (Vol. 2) Vertebres. FAO, Rome, 1301-1319.

Bloch ME, Schneider JG (1801) Systema Ichthyologiae iconibus cx illustratum. Berolini. Sumtibus Austoris Impressum et Bibliopolio Sanderiano Commissum, Berolini, 584 pp.

Bloch ME (1790) Naturgeschichte der ausländischen Fische (Vol. 4). Bey der Königl. Akademisken Kusthändlern J. Molino \& Comp., Berlin, 128 pp. 
Bonnet J, Rodriguez A (1992) Fauna Marina Amenazada en las Islas Canarias. Instituto para la Conservacion del Medio Ambiente (ICONA), Madrid, 296 pp.

Brünnich MT (1768) Ichthyologia Massiliensis, sistens piscium descriptiones eorumque apud incolas nomina. Accedunt Spolia Maris Adriatici, Hafniae et Lipsiae, 110 pp. https://doi. org/10.5962/bhl.title.5782

Carvalho Filho A, Ferreira CEL (2013) A new species of dwarf sea bass, genus Serranus (Serranidae: Actinopterygii), from the southwestern Atlantic Ocean. Neotropical Ichthyology 11(4): 809-814. https://doi.org/10.1590/S1679-62252013000400008

Clement M, Posada D, Crandall KA (2000) TCS: a computer program to estimate gene genealogies. Molecular Ecology 9(10): 1657-1659. https://doi.org/10.1046/j.1365294x.2000.01020.x

Collins RA, Cruickshank RH (2013) The seven deadly sins of DNA barcoding. Molecular Ecology Resources 13(6): 969-975. https://doi.org/10.1111/1755-0998.12046

Collins RA, Boykin LM, Cruickshank RH, Armstrong KF (2012) Barcoding's next top model: an evaluation of nucleotide substitution models for specimen identification. Methods in Ecology and Evolution 3: 457-465. https://doi.org/10.1111/j.2041-210X.2011.00176.x

Cuvier G, Valenciennes A (1828) Histoire Naturelle des Poissons. Tome second. Chez F.G. Levrault, Paris-Strasbourg and Bruxelles, $490 \mathrm{pp}$.

Dooley JK, Tassell JV, Brito A (1985) An annotated checklist of shorefishes of the Canary Islands. American Museum Novitates 2824: 1-49.

Excoffier L, Lischer HE (2010) Arlequin suite ver. 3.5: a new series of programs to perform population genetics analyses under Linux and Windows. Molecular Ecology Resources 10: 564-567. https://doi.org/10.1111/j.1755-0998.2010.02847.x

Froese R, Pauly D (2020) FishBase. http://www.fishbase.org [Accessed 22-10-2020]

Fernholm B, Wheller A (1983) Linnaean fish specimens in the Swedish Museum of Natural History, Stockholm. Zoological Journal of the Linnean Society 78: 199-286. https://doi. org/10.1111/j.1096-3642.1983.tb00867.x

Gunther A (1859) Catalogue of the Acanthopterygian Fishes in the Collection of the British Museum. First volume. Taylor and Francis, London, 524 pp.

Heemstra PC, Randall JE (1993) FAO Species Catalogue: Groupers of the World (Family Serranidae, Subfamily Epinephelinae). An Annotated and Illustrated Catalogue of the Grouper, Rockcod, Hind, Coral grouper and Lyretail Species Known to Date. FAO Fish Synopsis 125. FAO, Rome, 382 pp.

Horton T, Kroh A, Ahyong S, Bailly N, Boury-Esnault N, Brandão SN, et al. (2020) World Register of Marine Species. https://www.marinespecies.org [Accessed on 22-10-2020]

IUCN (2020) The IUCN Red List of Threatened Species. http://www.iucnredlist.org/search [Accessed on 22-10-2020]

Iwamoto T, Wirtz P (2018) A synopsis of the eastern and central Atlantic combers of the genus Serranus (Teleostei: Scorpaeniformes: Serranidae). Proceedings of the California Academy of Sciences (Series 4) 65(1): 1-39.

Kearse M, Moir R, Wilson A, Stones-Havas S, Cheung M, Sturrock S, Buxton S, Cooper A, Markowitz S, Duran C, Thierer T, Ashton B, Mentjies P, Drummond A (2012) Geneious 
Basic: an integrated and extendable desktop software platform for the organization and analysis of sequence data. Bioinformatics 28: 1647-1649. https://doi.org/10.1093/bioinformatics/bts 199

Kumar S, Stecher G, Tamura K (2016) MEGA7: Molecular Evolutionary Genetics Analysis version 7.0 for bigger datasets. Molecular Biology and Evolution 33(7): 1870-1874. https://doi.org/10.1093/molbev/msw054

Linnaeus C (1758) Systema naturæ per regna tria naturæ, secundum classes, ordines, genera, species, cum characteribus, differentiis, synonymis, locis. Tomus I. Editio decima, reformata. Laurentius Salvius, Holmiae, 824 pp. https://doi.org/10.5962/bhl.title.542

Linnaeus C (1764) Museum Adolphi Friderici regis Svecorum, Gothorum, Vandalorumque. Tomi secondi. Laurentius Salvius, Holmiae, 110 pp.

Lloris D, Rucabado J (1998) Guide FAO d'Identification des Espèces pour les Besoins de la Pêche. Guide d'Identification des Ressources Marines Vivantes du Maroc. FAO, Rome, 263 pp.

Naylor GJP, Caira JN, Jensen K, Rosana KAM, White WT, Last PR (2012) A DNA sequencebased approach to the identification of shark and ray species and its implications for global elasmobranch diversity and parasitology. Bulletin of the American Museum of Natural History 367: 1-262. https://doi.org/10.1206/754.1

NCBI (2020) National Center for Biotechnology Information Search database. https://www. ncbi.nlm.nih.gov/ [Accessed on 22-09-2020]

Parenti P, Randall JE (2020) An annotated checklist of the fishes of the family Serranidae of the world with description of two new related families of fishes. FishTaxa 15: 1-170.

Peters W (1865) Las über Bloch'sche Arten der Fisch-Gattung Serranus. Monatsberichte der Königlichen Preufs. Akademie der Wissenschaften zu Berlin 1865: 97-111.

Ratnasingham S, Hebert PDN (2007) BOLD: the Barcode of Life Data System (www.barcodinglife.org). Molecular Ecology Notes 7: 355-364. https://doi.org/10.1111/j.14718286.2007.01678.x

Rozas J, Ferrer-Mata A, Sánchez-DelBarrio JC, Guirao-Rico S, Librado P, Ramos-Onsins SE, Sánchez-Gracia A (2017) DnaSP 6: DNA Sequence Polymorphism analysis of large datasets. Molecular Biology and Evolution 34: 3299-3302. https://doi.org/10.1093/molbev/msx248 Smith-Vaniz WF (2015) Serranus scriba. The IUCN Red List of Threatened Species. https://doi. org/10.2305/IUCN.UK.2015-4.RLTS.T198713A42691914.en [Accessed 22-09-2020]

Spinola M (1807) Lettre sur quelques poissons peu connus du Golfe de Gênes, adressée à M. Faujas-de-Saint-Fond. Annales du Museum d'Histoire Naturelle Paris 10: 366-380. https://doi.org/10.5962/bhl.title.9110

Srivathsan A, Meier R (2012) On the inappropriate use of Kimura-2-parameter (K2P) divergences in the DNA-barcoding literature. Cladistics 28: 190-194. https://doi.org/10.1111/ j.1096-0031.2011.00370.x

Thompson JD, Higgins DG, Gibson TJ (1994) CLUSTALW: improving the sensitivity of progressive multiple sequence alignment through sequence weighting, position-specific gap penalties and weight matrix choice. Nucleic Acids Resources 22: 4673-4680. https://doi. org/10.1093/nar/22.22.4673 
Tuset VM, Garcia-Diaz MM, Gonzalez JA, Lorente MJ, Lozano IJ (2005) Reproduction and growth of the painted comber Serranus scriba (Serranidae) of the Marine Reserve of Lanzarote Island (central-eastern Atlantic). Estuarine, Coastal and Shelf Science 64: 335-346. https://doi.org/10.1016/j.ecss.2005.02.026

Valenciennes A (1832) Additions et Corrections Aux Tomes II, III, IV, V, VII et VIII. In: Cuvier G, Valenciennes A (Eds) Histoire naturelle des poissons. Tome huitième. F.G. Levrault, Paris, Strasbourg-Bruxelles, 471-509.

Vella A, Vella N, Schembri S (2017) A molecular approach towards taxonomic identification of elasmobranch species from Maltese fisheries landings. Marine Genomics 36: 17-23. https://doi.org/10.1016/j.margen.2017.08.008

Ward RD, Zemlak TS, Innes BH, Last PR, Hebert PDN (2005) DNA barcoding Australia's fish species. Philosophical Transactions of the Royal Society B - Biological Sciences 360(1462): 1847-1857. https://doi.org/10.1098/rstb.2005.1716

Wirtz P, Iwamoto T (2016) A new species of Serranus from São Tomé and Príncipe, eastern Atlantic (Pisces Teleostei, Serranidae). Proceedings of the California Academy of Sciences (Series 4) 63(6): 191-200.

Zorica B, Sinovcic G, Jardas I (2010) Morphometric and meristic characteristics of Painted Comber, Serranus scriba (L. 1758), in the Trogir Bay area (eastern mid-Adriatic). Periodicum Biologrum 112(2): 139-143.

\section{Supplementary material I}

\section{Tables S1-S3, Figures S1, S2}

Authors: Adriana Vella, Noel Vella, Carolina Acosta-Díaz

Data type: tables and images

Copyright notice: This dataset is made available under the Open Database License (http://opendatacommons.org/licenses/odbl/1.0/). The Open Database License $(\mathrm{ODbL})$ is a license agreement intended to allow users to freely share, modify, and use this Dataset while maintaining this same freedom for others, provided that the original source and author(s) are credited.

Link: https://doi.org/10.3897/zookeys.1017.60637.suppl1 